\title{
Ownership Structure, Corporate Governance, And Firm Value: Evidence from the East Asian Financial Crisis
}

\author{
By: Michael Lemmon and Karl Lins
}

William Davidson Working Paper Number 393

April 2001 


\title{
Ownership Structure, Corporate Governance, And Firm Value: Evidence from the East Asian Financial Crisis
}

\author{
Michael L. Lemmon and Karl V. Lins*
}

This Draft: April 11, 2001

JEL Classification: G15, G32, G34

Key Words: Financial Crises, Corporate Governance, Ownership Structure

*Michael Lemmon and Karl Lins are Assistant Professors of Finance at the David Eccles School of Business at the University of Utah. 1645 E. Campus Dr. Rm. 109, Salt Lake City, UT 84112-9303. Lemmon can be reached at (801) 585-5210 or at finmll@business.utah.edu. Lins can be reached at (801) 585-3171 or at finkvl@business.utah.edu. Both authors thank the Center for International Business and Economic Research (CIBER) for providing funding for this project. Additionally, we thank Stijn Claessens and Simeon Djankov for providing access to the handbooks used in World Bank East Asia ownership studies, and Todd Mitton and Leora Klapper for helpful comments. 


\title{
Ownership Structure, Corporate Governance, And Firm Value: Evidence from the East Asian Financial Crisis
}

\begin{abstract}
We study the effect of ownership structure on firm value during the East Asian financial crisis that began in July 1997. The crisis represents a negative shock to the investment opportunities of firms in these markets that raises the incentives of controlling shareholders to expropriate minority shareholders. Moreover, the large separation between cash flow and control rights that often arise from the use of pyramidal ownership structures and cross-holdings in these markets suggests that insiders have both the incentive and the ability to engage in expropriation. Using data from over 800 firms in eight East Asian countries, we find evidence consistent with this view. Tobin's $Q$ ratios of those firms in which minority shareholders are potentially most subject to expropriation decline twelve percent more than $Q$ ratios in other firms during the crisis period. A similar result holds for stock returns - firms in which minority shareholders are most likely to experience expropriation underperform other firms by about nine percent per year during the crisis period. Further, during the pre-crisis period we find no evidence that firms with a separation between cash flow rights and control rights exhibit performance changes different from firms with no such separation. All of these results are robust to controls for country and industry effects, as well as proxies for differences in risk across firms and the strength of the country's legal institutions. The evidence indicates that corporate ownership structure plays an important role in determining the incentives of insiders to expropriate minority shareholders during times of declining investment opportunities. Our results add to the literature that examines the link between ownership structure and firm performance and provide additional guidance to policymakers engaged in the ongoing debate about the proper role and design of corporate governance features and legal institutions in developing economies.
\end{abstract}




\section{Introduction}

Beginning in July 1997, many East Asian emerging markets experienced prolonged financial crises. The effects of these crises also spread to other emerging markets in Latin America, the Middle East, and Eastern Europe as investors perceived other countries to be vulnerable as well. As a result, many countries experienced large exchange rate depreciations and stock market crashes. While the crisis affected nearly all of the emerging markets, there were significant differences in the extent of exchange rate depreciation and stock market declines across countries (World Bank 2000).

One explanation of why some countries and firms fared better than others during the crisis period relies on differences in the strength of legal institutions and the structure of corporate governance mechanisms that prevent the expropriation of minority shareholders. If expropriation of minority shareholders increases when the expected rate of return on investment falls, then an adverse shock to investment opportunities will lead to increased expropriation, as well as reduced capital inflows and greater attempted capital outflows for a country. Consistent with this view, Johnson, Boone, Breach, and Friedman (hereafter JBBF) (2000) study countrylevel data and find that the extent of exchange rate depreciation and stock market performance are indeed correlated with aggregate measures of legal protection.

In this paper, we examine whether differences in ownership structure at the firm level can explain differences in firm performance during the recent East Asian financial crisis. The crisis period offers an interesting opportunity to study the effects of ownership structure on firm value because of the substantial cross-sectional variation in both the costs and benefits of expropriating minority investors across firms and countries. In order for expropriation of minority shareholders to occur, insiders (controlling shareholders and managers) must have both the 
ability and the desire to divert funds for their private benefit. ${ }^{1}$ The ability of managers to engage in expropriation is directly related to their degree of control of the company, while their desire to engage in expropriation is directly related to the consequences of their actions on the cash flows obtained from their shareholdings in the firm. La Porta, Lopez-de-Silanes, Shleifer and Vishny (hereafter LLSV) (1998) and La Porta, Lopez-de-Silanes, and Shleifer (hereafter LLS) (1999) show that ownership structures vary widely across firms and countries. Claessens, Djankov, and Lang (2000) and Lins (2000) show that the widespread use of pyramidal ownership structures in many emerging market firms allows insiders to exercise effective control over a company, despite owning relatively few of its cash flow rights.

We hypothesize that, all else equal, firms in which insiders hold substantial control rights, but have low cash flow rights should be the most subject to expropriation during the crisis period. Using detailed ownership data from over 800 firms in eight East Asian countries, we test the above hypothesis by examining cross-sectional variation in measures of changes in firm value during the crisis period as a function of the firm's ownership structure and the strength of the country's legal institutions.

In our sample, the management group and its family members own an average of $26 \%$ of a firm's control rights. We find that the mean ratio of the management group's control rights to its cash flow rights, a measure we call cash flow rights leverage, is greater than 2.0. We also observe that the management group has the largest blockholding of control rights in two thirds of our sample firms. These findings indicate that, in many East Asian firms, managers are able to effectively control the firm even though they may have relatively low cash flow ownership. In

\footnotetext{
${ }^{1}$ For example, United Engineers Malaysia, a healthy firm with strong growth prospects, bought out some management-controlled shares of its financially troubled parent, Renong Corporation, at artificially high prices.
} 
addition, we find substantial variation across firms and countries in the separation between ownership and control. If the structure of corporate ownership is an important determinant of the degree of expropriation in times of declining investment opportunities, then we expect firm value during the crisis period to decline the most in firms where insiders hold high levels of control rights, but relatively few of the firm's cash flow rights.

Consistent with this hypothesis, we find that Tobin's $Q$ ratios of those firms in which minority shareholders are potentially most subject to expropriation decline twelve percent more than $Q$ ratios in other firms during the crisis period. A similar result holds for stock returns firms in which minority shareholders are most likely to experience expropriation underperform other firms by about nine percent per year during the crisis period. These results are robust to controls for country and industry effects as well as proxies for differences in risk across firms and the strength of the country's legal institutions. Also consistent with our predictions, we find no differences in annual changes in firm performance between firms with and without cash flow rights leverage prior to the crisis. Overall, we find strong support for the view that management's 'leverage' of cash flow ownership into greater effective control of the firm enhances the incentives to expropriate minority shareholders during the crisis period.

Our work is related to several strands of the corporate governance literature. As mentioned, JBBF (2000) find that countries with stronger legal protections for minority shareholders experienced less severe exchange rate depreciation and stock market declines during the crisis than countries with weaker legal protections. ${ }^{2}$ These authors focus primarily on

Both firms are controlled by the same family. The buyout directly transferred wealth to the family at the expense of minority shareholders of both firms (Moore (1998)).

${ }^{2}$ They also show that measures of legal protection provide at least as convincing an explanation of the extent of exchange rate depreciation and stock market declines as the usual macroeconomic arguments. Macroeconomic explanations that are documented include allegations of inappropriate macroeconomic policy in these countries 
differences in the legal systems and strength of legal enforcement across different countries, although their intuition and model is motivated at the firm level. We focus primarily on differences in ownership structure at the firm level, while controlling for the legal regime of the country and other factors. In a similar vein, Mitton (2000) studies five East Asian countries at the firm level and finds evidence that firms with greater disclosure performed better than other firms during the crisis period. In contrast to our findings, however, he finds little evidence that the separation of cash flow and control rights affects firm performance during the crisis period. Claessens, Djankov, and Klapper (1999) find that East Asian controlled by management/family groups were less likely to file for bankruptcy during the crisis. They argue that this insurance against bankruptcy may come at the expense of minority shareholders. Finally, Rajan and Zingales (1998) argue that, despite inadequate protection ex ante, the use of arm's length capital (i.e. a market-based and contractual framework) in East Asia worked fine before the crisis, but could not provide safeguards against expropriation during the crisis, leading to minority investors rationally exiting the market.

Our work is also related to papers by Claessens, Djankov, Fan, and Lang (2000), Johnson, La Porta, Lopez-de-Silanes, and Shleifer (2000), LLSV (2000), and Lins (2000) who examine the relation between firm value and ownership structure and the strength of legal institutions. ${ }^{3}$ Collectively, these studies encompass both developed and emerging markets and find that firm value is positively related to measures of investor protection and to the cash flow rights held by the management group and negatively related to the separation of management

during the early 1990s, a mild panic made worse by forced bank closures, and implausible implicit bank guarantees that led to a bubble in asset prices.

${ }^{3}$ See also Nenova (2000) who, based on evidence from multiple classes of stock, finds that the value of control rights varies substantially across countries as a function of the legal protections afforded to minority shareholders. In East Asian firms, the leverage of cash flow rights into control rights is generally accomplished through pyramidal ownership structures and cross-holdings rather than through multiple classes of stock with differing voting rights. 
group cash flow and control rights. We add to this literature by examining changes (rather than levels) in firm value in emerging markets (where differences in corporate governance should matter most) during the crisis period (when differences in corporate governance should matter most). In doing so, we are able construct powerful tests of the relation between corporate governance and firm performance.

Finally, to the extent that the crisis represents a relatively exogenous event, we avoid some of the endogeneity issues that arise because ownership structure and firm value may be jointly determined. In this sense we contribute to the broader literature that examines the link between ownership structure and firm value (e.g., Demsetz and Lehn (1985), Morck, Shleifer, and Vishny (1988), McConnell and Servaes (1990), and Himmelberg, Hubbard and Palia (1999)). Our results provide additional guidance to policymakers engaged in the ongoing debate about the proper role and design of corporate governance features and legal institutions in developing economies.

The remainder of the paper is organized as follows. Section II uses a simple model to illustrate our hypotheses. Section III describes the sample and presents the results of the empirical analysis. Section IV concludes with a brief summary.

\section{Hypothesis Development}

To illustrate our hypotheses we use a variation of the model presented in JBBF (2000). The manager owns a share $\alpha$ of the cash flows generated by the firm and outsiders own a share 1- $\alpha$. Retained earnings are denoted by I. The manager can divert $S \geq 0$ of the retained earnings for his personal benefit and obtains utility S from them. In this setting, S represents the amount 
of the firm's profits that can be expropriated from all shareholders, including minority shareholders.

In our version of the model, we emphasize the role that ownership structure plays in determining the incentives for expropriation. We assume that expropriation is costly and the manager expects to lose $C(S)=\left(S^{2} / 2 k \alpha\right)$ from the amount expropriated. In this setting, $k$ represents the ability of the manager to lever his cash flow rights into higher control rights through the use of pyramidal ownership structures and/or by holding shares with superior voting rights. A higher value of $\mathrm{k}$ implies that expropriation is less costly because managers enjoy more effective control over the firm. In our sample, the mean value of cash flow rights leverage, $\mathrm{k}$, is 2.16, and the mean level of control rights, $\mathrm{k} \alpha$, held by insiders is 0.264 . These findings indicate that there is a substantial wedge between the control rights and cash flow rights held by insiders in the East Asian countries we study. With these assumptions, the value of $\mathrm{S}-\mathrm{C}(\mathrm{S})$ is concave in $\mathrm{S}$, such that the marginal value of expropriation falls as the amount of expropriation increases.

The manager invests the retained earnings in excess of the amount expropriated in a project with return $\mathrm{R}>1$, from which he obtains a share $\alpha$ of the profits. The optimization problem of the manager is given by:

$$
\operatorname{Max}_{S} U(S ; R, k, \alpha)=\operatorname{Max}_{S}\left[\alpha R(I-S)+S-\left(S^{2} / 2 k \alpha\right)\right]
$$

The formulation of the manager's maximization problem captures both the incentive and entrenchment effects of ownership structure. The first term in brackets on the right hand side of equation (1) captures the incentive effect of ownership. The level of cash flow rights, $\alpha$, in this term represents the cost to the manager of expropriating more and thus investing less in the project. The third term in equation (1) captures the entrenchment effect. As the manager's level 
of overall control rights, $\mathrm{k} \alpha$, increases, the costs of expropriation fall. Solving this optimization problem for the optimal amount of expropriation yields:

$S^{*}(R, k, \alpha)=k \alpha(1-\alpha R)$

We assume parameter values are such that the total amount of expropriation is less than the amount of retained earnings, I. The total value of the firm's equity is the total value of the firm minus the value expropriated, which is given by:

$\Pi=R(I-k \alpha(1-\alpha R))$

We are most interested in how the amount expropriated and, in turn, firm value will change with a change in the attractiveness of the firm's investment opportunities. Following JBBF (2000), we focus on the percentage change in firm value with respect to a change in the return on investment, which is given by:

$\rho_{r}=\frac{\partial \Pi / \partial R}{\Pi}=\frac{\left(I-k \alpha(1-\alpha R)+R k \alpha^{2}\right)}{R(I-k \alpha(1-\alpha R))}$

To investigate how differences in cash flow rights leverage will be reflected in firm value when the attractiveness of investment opportunities changes, we differentiate the above equation with respect to $\mathrm{k}$.

$$
\frac{\partial \rho_{r}}{\partial k}=\frac{I \alpha^{2}}{(I-k \alpha(1-R \alpha))^{2}}>0
$$

This comparative static result is the basis of our primary hypothesis. For a given level of cash flow ownership, $\alpha$, higher cash flow rights leverage, $\mathrm{k}$, lowers the cost of expropriation. This implies that changes in firm value are more sensitive to changes in investment opportunities when managers have substantial cash flow rights leverage. 
H1: The change in firm value resulting from a shock to investment opportunities, $R$, is increasing in the degree of cash flow rights leverage, k. Furthermore, the sensitivity of firm value to changes in investment opportunities is increasing in the level of overall control rights, $\mathrm{k} \alpha$, held by the manager.

The East Asian financial crisis that began in July 1997 represents a large negative shock to the investment opportunities of firms in the affected countries. Our hypothesis predicts that firm values should decline the most in firms where managers hold high levels of control rights but have substantial cash flow rights leverage.

\section{Data and Empirical Analysis}

\section{A. Sample selection and summary statistics}

Panel A of Table 1 describes our sample selection process. We begin by collecting financial data from Worldscope for all firms from Hong Kong, Indonesia, Malaysia, the Philippines, Singapore, South Korea, Taiwan, and Thailand that are covered by the July 1997 version of Worldscope in order to capture firms in existence prior to onset of the crisis. These eight emerging markets are the same ones studied by Claessens, Djankov, Fan, and Lang (2000). The firms covered by Worldscope at this time represent approximately 90 percent of the stock market capitalization of these East Asian countries. We eliminate firms whose primary business is financial services (SICs 6000-6999), resulting in an initial sample of 1,396 firms. We next match this initial sample of firms with ownership data from Lins (2000), which contains data from the 1995/1996 time period on the control rights and cash flow rights held by managers and 
their families for non-financial firms in 18 emerging markets. We lose 457 firms because of a lack of ownership data. ${ }^{4}$

We require that a firm is covered by Worldscope in both the pre-crisis and post-crisis period. Since the crisis clearly began in July of 1997, we define our pre-crisis period as fiscal year-ends between July, 1996 and June, 1997. We next need to specify the time period in which the crisis effect on valuation is to be measured. There is no clear consensus on exactly when the crisis ended, but returns from the MSCI country indices indicate that East Asian markets were improving substantially by July, 1998. We want to maintain a consistent period of time (one year in this case) for the crisis to affect our firms, so we define our post-crisis period as fiscal year-ends between July, 1997 and June, 1998 and use later versions of Worldscope to obtain this financial data. ${ }^{5}$ This choice of post-crisis period could obviously understate the effect of the crisis for firms with fiscal year-ends on or just after July. Fortunately, the overwhelming majority of our firms have fiscal year-ends between December and June. For robustness, we perform other analyses to ensure that our results are not biased by crisis period measurement issues.

We exclude firms with SEDOL changes or insufficient data to calculate Tobin's $Q$ ratio in both the pre- and post-crisis period. Tobin's $Q$ ratio is defined as the ratio of total liabilities plus the market value of equity divided by the book value of total assets. Our final sample consists of 853 firms for which we have both ownership and financial data over the crisis period. We also collect monthly stock return data in local currency from Datastream. Stock returns are not available for 60 of our sample firms. We focus on changes in firm value measured in local

\footnotetext{
${ }^{4}$ Lins (2000) shows that there are no statistically significant differences between firms with and without ownership data, suggesting that the lack of ownership data for some firms does not bias the sample in any particular manner.
} 
currency because we are interested in the effects of differences in ownership on firm performance across firms within countries. By measuring performance in local currency we net out any effects of exchange rates that are common to all firms within each country.

In our empirical analysis, we use two measures of the change in firm value during the crisis period. The first is the difference in the natural logs of the post-crisis and pre-crisis values of Tobin's $Q$ (i.e., the continuously compounded percentage change in Tobin's $Q$ ), and the second is the compound return on the firm's stock in local currency. We measure stock returns over the period July 1997 to July 1998; the one-year crisis period. As control variables, we use firm size measured as the book value of assets converted to U.S. dollars using the exchange rate provided by Worldscope and the firm's ratio of total debt to total assets. The control variables are measured at the end of the firm's fiscal year closest to year end 1995 (prior to the beginning of the crisis) in order to avoid any spurious correlation between these variables and our measures of changes in firm value during the crisis. We also include the country's rule of law score from LLSV (1998). The rule of law score ranges from zero to ten with lower scores corresponding to less tradition for law and order. Summary statistics for the overall sample are shown in Panel B of Table 1.

As expected, the panel shows a substantial decline in firm values during the crisis period. Tobin's $Q$ values decreased by 24 percent while stock returns declined by almost 50 percent, on average. The average total assets of firms in the sample is 912 million USD and the average leverage ratio 0.295 . The average rule of law score is 6.91 .

\footnotetext{
${ }^{5}$ We verify that historical financial data from more recent Worldscope disks almost always matches with that reported in 1997. Where it does not match, we use the updated data from the most recent disk. Our results remain unchanged if we remove firms with such discrepancies from our sample.
} 
Ownership statistics for these eight East Asian countries closely track those reported in Lins (2000) for a larger emerging markets sample. The control rights held by a firm's officers and directors and their families, which we refer to as the management group, average 26.4 percent across the sample. These control rights include direct ownership as well as the effect of those stakes obtained indirectly via management group ownership and control of blockholders in the firm (i.e. pyramid ownership). The next variable in the table is 'Cash flow rights leverage' which is computed as management group control rights divided by the cash flow rights associated with those control rights. This measure will be greater than unity where indirect management ownership occurs. ${ }^{6}$ The table reports an average cash flow rights leverage of 2.16 which means that the typical management group is able to turn one cash flow ownership right into over two control rights. This measure is winsorized at a value of 10 (the $95^{\text {th }}$ percentile).

Table 2 presents the summary statistics by country. As seen in the table, there is substantial variation in our measures across countries. Malaysian firms had by far the largest percentage decline in Tobin's $Q$ values and the second largest decline in average stock returns. Note that there is imperfect correlation between the Tobin's $Q$ measure and the cumulative stock return measure of changes in firm value. Firms from Hong Kong, Indonesia, Korea, and Thailand had broadly similar average percentage declines in $Q$ over the crisis, yet their percentage stock return declines were widely divergent. In our empirical analysis, we employ both valuation measures for robustness.

Management group ownership also varies substantially across countries. The managers and their families hold relatively few control rights in Korea, Taiwan, and Thailand. At the same

\footnotetext{
${ }^{6}$ This measure will also be greater than unity if shares with superior voting rights held by the management group; however, despite their prevalence in other emerging markets, Lins (2000) documents that such shares are almost never employed in these eight East Asian countries.
} 
time, Korean and Taiwanese managers still make extensive use of mechanisms that separate their control rights from their cash flow rights as evidenced by their relatively high cash flow rights leverage values. ${ }^{7}$ Table 2 also shows that Korean firms are substantially larger than firms from other East Asian countries and that both they and firms from Thailand have relatively high levels of debt. Finally, the rule of law scores range from a low of 2.73 in the Philippines to a high of 8.22 in Hong Kong, indicating substantial variation in the rule of law across countries.

\section{B. The effects of ownership structure on firm value during the crisis}

Our primary hypothesis is that, all else equal, firms in which insiders own a majority of the control rights, but few of the cash flow rights, will exhibit the largest declines in firm value during the crisis. To provide some preliminary evidence on this issue, Table 3 presents univariate comparisons of the change in Tobin's $Q$ and stock returns for firms with high and low cash flow rights leverage for the overall sample and for subsamples based on the level of the control rights held by the management/family group. We first divide firms into two groups based on whether they have cash flow rights leverage that is greater than unity. Panel A of the table compares our measures of firm performance during the crisis period across these two groups of firms. The mean percentage change in Tobin's $Q$ for firms in the high cash flow rights leverage group is -0.337 compared to -0.209 for firms in the low cash flow rights leverage group. The difference of -0.128 is significant at the one percent level. Firms with high cash flow rights leverage also exhibit worse stock returns. The mean return for this group is -0.534

\footnotetext{
${ }^{7}$ At first glance, the mean values of management control rights and cash flow rights leverage appear different from those reported for some countries in Tables 4 and 5 of Claessens, Djankov, and Lang (2000). However, this can likely be attributed to different reporting specifications. We tabulate managerial ownership data for all firms in a country, whereas Claessens, et al. tabulate control rights for the largest shareholder of a firm (which may not be the management/family group) and tabulate the separation of control and cash flow rights for only those firms with a 20 percent or larger blockholder.
} 
compared to a mean return of -0.448 for firms with low cash flow rights leverage. The difference of -0.086 is also significant at the one percent level. Similar patterns are found based on medians, although the difference in stock returns is not significant at conventional levels.

The table also indicates that the use of cash flow rights leverage is positively correlated with the level of control rights. In the high cash flow rights leverage group the mean ownership of control rights is 0.43 and the level of cash flow rights leverage is 5.25 , on average. The corresponding values for firms in the low cash flow rights leverage group are 0.20 and 1 . Finally, the firms in the two groups are of roughly similar size, but firms in the high cash flow rights leverage group have somewhat lower financial leverage. This last finding suggests that differences in risk arising from differences in leverage are unlikely to explain our results. Overall, the evidence is consistent with our hypothesis. Firms with high cash flow rights leverage exhibit significantly worse performance during the crisis period relative to firms with low cash flow rights leverage.

Panels $\mathrm{B}$ and $\mathrm{C}$ in Table 3 further separate firms based on the overall level of control rights held by the management group. Our analysis in Section II suggests that the effect of the separation of ownership and control on firm value should be the largest in firms where managers have a high level of control rights. Using an independent sort, we group firms into two subsamples based on whether the level of management group control rights are above or below the median in that country. By sorting firms within each country, we are able to partially control for cross-country differences in ownership structure. As an alternative measure of the degree of effective control, we also sort firms into two groups based on whether the management group is the largest blockholder in the firm. 
Panel B of the table presents results of subsamples based on the overall level of control rights. Consistent with our hypothesis, the table shows that the negative effect on valuation of the separation of control rights from cash flow rights is present only in those firms with relatively high management control rights ownership. Within this high management control rights subsample, firms for which the management group employs cash flow rights leverage to obtain its control have percentage declines in Tobin's $Q$ that are 17 percent larger compared with high management control firms in which managers hold only direct equity stakes. Similar declines are found using the cumulative stock return measure of changes in firm value. High management control rights firms which also have high cash flow rights leverage display 13.5 percent greater declines in stock returns than those with no cash flow rights leverage. Both of these results are significant at the one percent level. In contrast, the third and fourth rows in Panel B of Table 3 show that cash flow rights leverage differences do not affect firm values when the management group has relatively low control rights. Within this subsample, the magnitude of the differential in both measures of firm value over the crisis period between firms with and without cash flow rights leverage is much smaller than that found for high management control firms. Further, the differences are statistically insignificant as well. It is interesting to note that there are relatively few firms (56 versus 391$)$ for which the management group has below-median control rights, yet still uses cash flow rights leverage in pursuit of those control rights.

Panel $\mathrm{C}$ of Table 3 also assesses whether cash flow rights leverage affects value more negatively when managers have greater effective control. In this panel, firms are separated based on whether or not the management group is the largest blockholder of control rights. Managers should be able to exercise greater discretion in their activities when they hold a plurality of a 
firm's control rights. Thus, this ownership measure is complementary to the previous measure of above-median managerial control rights used to gauge effective managerial control. Given the overall high levels of managerial control rights of our sample firms, it is not surprising that the management group is the largest blockholder of control rights 67 percent of the time.

The results of Table 3, Panel C track those reported in Panel B. Within the subsample of firms in which the management group is the largest blockholder, firms for which the management group also employs cash flow rights leverage to obtain its control again have percentage declines in Tobin's $Q$ that are 18 percent greater compared to firms which have no cash flow rights leverage. The difference is 9.4 percent when cumulative stock returns are used as the valuation measure and, again, both of these differences are statistically significant. The latter rows of Panel $\mathrm{C}$ show that cash flow rights leverage differences do not affect changes in firm value when there is a larger outside blockholder present in a firm's ownership structure, a situation in which management may not be in effective control of the firm.

\section{Multivariate Analysis}

The univariate tests provide preliminary evidence consistent with our main hypothesis. However, to control for other variables in addition to ownership structure that differ across firms and countries and that may affect firm value we use a regression framework. The dependent variables in our regressions are the percentage change in Tobin's $Q$ and the cumulative stock return over the crisis period. To measure the effects of ownership structure we use an indicator variable equal to one for firms with cash flow rights leverage greater than unity. If high cash flow rights leverage increases the incentives for expropriation of minority shareholders during the crisis, we expect the coefficient estimate on this variable to be negative. As additional 
control variables we include the country's rule of law, firm size, and the ratio of debt to total assets, as well as dummy variables for industry at the 2-digit SIC code level. We use a random effects estimator to control for additional unmodeled effects at the country level. We use random effects rather than fixed effects so that we can separately examine the effect of the country's rule of law (e.g., LLSV (2000) and JBBF (2000)). Additionally, a Hausman tests fails to reject the use of a random effects model. In the regression analyses, we delete observations where the percentage change in Tobin's $Q$ is below the $1^{\text {st }}$ percentile and greater than the $99^{\text {th }}$ percentile to reduce any effects of outliers. We obtain similar results when we use untruncated data.

The results of these regressions using the change in Tobin's $Q$ as the dependent variable are shown in Table 4. The first model presents results for the full sample of 837 firms. The coefficient estimate on the cash flow rights leverage indicator variable is -0.123 ( $p$-value $=0.00$ ). The magnitude of the coefficient indicates that the Tobin's $Q$ ratios of firms with cash flow rights leverage greater than unity declined by 12 percent more compared to firms with no cash flow rights leverage. The rule of law variable is positive and significant ( $p$-value $=0.02$ ), indicating that firms in countries with stronger legal protections fared better than firms in countries with weak legal protection of minority shareholders. This finding is similar to that in JBBF (2000), who find that overall stock market returns during the crisis are positively correlated with measures of the strength of countries' legal institutions. It is also similar to findings presented in LLSV (2000) that the level of $Q$ is positively related to a country's legal protection. We also find that the change in Tobin's $Q$ is positively associated with firm size and firm leverage.

The second and third sets of regressions in the table report the results for subsamples based on our two measures of the overall level of control rights held by the management group. 
Models (2) and (3) report results based on firms that have above- and below-median management group control rights, respectively. In both subsamples, the change in Tobin's $Q$ is negatively related to cash flow rights leverage. We also see that the effects of cash flow rights leverage on the change in Tobin's $Q$ are slightly smaller in firms where management has low control rights. This result provides some weak evidence consistent with the view that the relation between changes in firm value and cash flow rights leverage should be the strongest in firms where managers own substantial control rights. Models (4) and (5) report the results of regressions for subsamples based on whether the management group is the largest blockholder. The results in these subsamples are more in line with our expectations. The effect of cash flow rights leverage on firm value is significantly negative only in the subsample of firms where the management group effectively controls the firm.

Table 5 repeats the regressions in Table 4, but uses stock returns over the crisis period as the dependent variable. Based on the full sample (model (1)), the results indicate that firms with cash flow rights leverage greater than unity underperform other firms by 9.3 percent (pvalue $=0.01$ ) over the crisis period after controlling for other factors. As expected, rule of law is positively related to stock returns ( $\mathrm{p}$-value $=0.00)$. In contrast to the results using the change in Tobin's $Q$ as the dependent variable, both firm size and leverage are negatively related to stock returns. This is likely due to the fact that Tobin's $Q$ is partially based on the firm's leverage ratio. Using stock returns we find somewhat stronger evidence that the negative effects of cash flow rights leverage are concentrated in firms where the management group effectively controls the firm. In models (2) through (5), the effects of cash flow rights leverage on stock returns are significant only in firms where managers have a high level of control. 


\section{An investor's perspective}

As a final way of looking at our results, we examine the performance of an investment strategy. Within the subsample of firms where managers have a high level of control rights, we form a zero-investment portfolio that purchases firms with low cash flow rights leverage and sells firms with high cash flow rights leverage. We equally weight firms in the portfolio and compute monthly returns to the portfolio over the 13 months from July 1997 through July 1998. The returns on this portfolio are approximately $1.4 \%$ per month. The returns are significant at the ten percent level based on the time-series standard deviation. ${ }^{8}$ This suggests that an investor who invested in firms with low cash flow rights leverage would have seen his wealth decline by $15 \%$ less than an investor who held firms with a high level of cash flow rights leverage during the crisis period. This finding should be viewed somewhat cautiously however, since we may not be completely controlling for differences in risk across firms with high and low cash flow rights leverage.

In summary, our results indicate that firms with high cash flow rights leverage significantly underperform other firms during the crisis period. Moreover, consistent with our expectations, the underperformance tends to be concentrated in firms where the management group has a high level of control. Taken together, these findings are consistent with the view that the separation between cash flow and control rights is an important determinant of the incentives of insiders to expropriate minority shareholders.

Our results are complementary to those of Claessens, Djankov, Fan, and Lang (2000) and Lins (2000) who both show that the level of firm value is negatively associated with a separation of cash flow ownership and control. They also complement the findings of LLSV (2000) that the

\footnotetext{
${ }^{8}$ Note that this significance level is based on only 13 observations.
} 
level of firm value is higher when the cash flow rights held by the controlling blockholder are higher. Importantly, in the spirit of Himmelberg, Hubbard, and Palia (1999), we focus on the effects of ownership structure on changes in firm value precipitated by a shock to the firm's investment opportunities. As such, our analysis potentially avoids some of the issues regarding the endogeneity of ownership structure and firm performance that may arise in a static analysis.

\section{E. The effects of ownership structure on firm value prior to the crisis}

As noted in JBBF (2000), the model in Section II suggests that the incentives to expropriate minority shareholders are much smaller when times are good. As seen from equation (2), the amount of expropriation is decreasing in the return on investment. This suggests that the effects of cash flow rights leverage on firm performance should be less evident prior to the crisis. We investigate this hypothesis in Table 6. The table reports regressions identical to those in Table 4, but where the dependent variable is the percentage change in Tobin's $Q$ over the one-year period preceding the crisis. As seen in Table 6, there is no evidence that firms with cash flow rights leverage greater than unity exhibit changes in performance different from firms with no cash flow rights leverage during the pre-crisis period. This result holds true in the full sample, as well as in all of the subsamples. Similar results obtain when we use one-year stock returns in the pre-crisis period as the dependent variable (not tabulated for brevity). These pre-crisis results provide further evidence consistent with the predictions of the model, and also provide additional confidence that the results we document during the crisis period are not spurious. 


\section{F. Other robustness tests}

We perform an additional test to help ensure that our Tobin's $Q$ results are not affected by differing fiscal year-ends across firms, in which we may fail to fully capture a year's worth of the crisis in some cases. In this test, we construct the $Q$ ratio using the book value of the closest reporting period preceding June 1997 as before, but we use the market value of the firm's equity from Datastream at the end of June 1997. This computation is intended to 'standardize' our precrisis Tobin's $Q$ measure. Similarly, for the post-crisis $Q$ measure we keep our same book values but use the market value of the firm's equity from Datastream at the end of June 1998. When we re-estimate the models of Table 4 with the standardized Tobin's $Q$ measure we find similar results. For brevity's sake these results are not shown in a table.

We also test whether or not our results obtain within the East Asian countries that have relatively low rule of law scores. In this analysis, we remove firms from Hong Kong, Singapore and Taiwan from the sample. In so doing, our five East Asian countries exactly match those studied by Mitton (2000). We again find strong and significant negative effects of cash flow rights leverage on changes in $Q$ and changes in stock returns during the crisis in this smaller sample. The regression coefficients are essentially the same in magnitude as those from the full sample and we also find that cash flow rights leverage only negatively affects those firms in which the management group is in effective control.

Because it can be argued that better disclosure may be associated with higher effective firm governance, we obtain information on the types of cross-listed securities, if any, that our sample firms have in their capital structure at the onset of the crisis. We separately categorize those securities for which the firm must reconcile its accounts to U.S. GAAP and adhere to SEC disclosure mandates (Level II and III ADRs and Yankee bonds) from those in which the firm 
does not have to provide any additional financial reporting or disclosure (Level I (OTC-traded) and Rule 144A ADRs). We construct indicator variables for firms that have the GAAP/disclosure securities and those that have Level I or 144A ADRs. We find that there are

relatively few U.S cross-listed securities of all types (80 cases) among our 853 sample firms and that only 8 of them are the type requiring GAAP and increased disclosure. We re-estimate our models from Tables 4 and 5 including these various dummy variables for different types of cross-listed securities and find that they are insignificant in all cases. The coefficients on cash flow rights leverage remain significant and are virtually unchanged (models not reported).

Finally, we also repeat our tests using the actual level of cash flow rights leverage in our regressions instead of the indicator variable for firms with cash flow rights leverage greater than unity. Although slightly weaker than the results reported in Tables 4 and 5, the coefficient on the level of cash flow rights leverage is negative and significant at better than the five percent level in the full sample regressions.

\section{Conclusions}

We study the effect of ownership structure on firm value during the East Asian financial crisis that began in July 1997. The crisis represents a negative shock to the investment opportunities of firms in these markets that raises the incentives of controlling shareholders to expropriate minority shareholders. Moreover, the large separation between cash flow and control rights that arises from the use of pyramidal ownership structures and cross-holdings in these markets suggests that insiders have both the incentive and the ability to engage in expropriation. 
Using data from over 800 firms in eight East Asian countries we find evidence consistent with this view. Tobin's $Q$ ratios of those firms in which minority shareholders are potentially most subject to expropriation decline 12 percent more than $Q$ ratios in other firms during the crisis period. A similar result holds for stock returns - firms in which minority shareholders are most likely to experience expropriation underperform other firms by about nine percent per year during the crisis period. Further, we find no evidence that firms with a separation between cash flow rights and control rights exhibit changes in performance different from firms with no such separation during the pre-crisis period. These results are robust to controls for country and industry effects as well as proxies for differences in risk across firms, and the strength of the country's legal institutions.

The evidence indicates that corporate ownership structure plays an important role in determining the incentives of insiders to expropriate minority shareholders during times of declining investment opportunities. Our results add to the literature that examines the link between ownership structure and firm performance and provide additional guidance to policymakers engaged in the ongoing debate about the proper role and design of corporate governance features and legal institutions in developing economies. 


\section{References}

Claessens, Stijn, Simeon Djankov, Joseph P.H. Fan, and Larry H.P. Lang, 2000, Expropriation of minority shareholders in East Asia, World Bank policy research working paper.

Claessens, Stijn, Simeon Djankov, and Larry H.P. Lang, 2000, The separation of ownership and control in East Asian corporations, Journal of Financial Economics 58.

Claessens, Stijn, Simeon Djankov, and Leora Klapper, 1999, Resolution of corporate distress: evidence from East Asia's financial crisis, World Bank policy research working paper.

Demsetz, Harold, and Kenneth Lehn, 1985, The structure of corporate ownership: causes and consequences, Journal of Political Economy 93, 1155-1177.

Himmelberg, Charles P., R. Glenn Hubbard and Darius Palia, 1999, Understanding the determinants of managerial ownership and the link between ownership and performance, Journal of Financial Economics 53, 353-384.

Johnson, Simon, Peter Boone, Alasdair Breach, and Eric Friedman, 2000, Corporate governance in the Asian financial crisis, Journal of Financial Economics 58.

Johnson, Simon, Rafael La Porta, Florencio Lopez-de-Silanes, and Andrei Shleifer, 2000, Tunneling, American Economic Review 90, 22-27.

La Porta, Rafael, Florencio Lopez-de-Silanes, Andrei Shleifer, and Robert W. Vishny, 1998, Law and finance, Journal of Political Economy 106, 1113-1155.

La Porta, Rafael, Florencio Lopez-de-Silanes and Andrei Shleifer, 1999, Corporate ownership around the world, Journal of Finance 54, 471-517.

La Porta, Rafael, Florencio Lopez-de-Silanes, Andrei Shleifer, and Robert W. Vishny, 2000, Investor protection and corporate valuation, Working paper, Harvard University and University of Chicago.

Lins, Karl V., 2000, Equity ownership and firm value in emerging markets, Working paper, University of Utah.

McConnell, John and Henri Servaes, 1990, Additional evidence on equity ownership and corporate value, Journal of Financial Economics 27, 595-612.

Mitton, Todd, 2000, A cross-firm analysis of the impact of corporate governance on the East Asian financial crisis, Working paper, Brigham Young University.

Moore, Jonathan, 1998, The deal smelled rotten - and it was, Business Week, June 8, 27. 
Morck, Randall, Andrei Shleifer, and Robert W. Vishny, 1988, Management ownership and market valuation: An empirical analysis, Journal of Financial Economics 20, 293-315.

Nenova, Tatiana, 2000, The value of corporate votes and control benefits: Cross-country analysis, Harvard University, working paper.

Rajan, Raghuram, and Luigi Zingales, Which capitalism? Lessons from the East Asian crisis, Journal of Applied Corporate Finance 11.

Shleifer, Andrei, and Robert W. Vishny, 1997, A survey of corporate governance, Journal of Finance 52, 737-783.

World Bank, 2000, Global Economic Prospects and the Developing Countries, Washington, DC, USA 


\section{Table 1}

Sample Selection Procedure and Summary Statistics

The Worldscope database is the source of all financial data for our sample. Panel A describes the sample selection procedure and Panel B reports summary statistics for the final sample. Financial firms refer to those with primary SIC codes in the 6000-6999 range. The pre-crisis period is defined as fiscal year-ends between July 1996 and June 1997 and the post-crisis period is defined as fiscal year-ends between July 1997 and June 1998. Tobin's $Q$ is computed as the book value of assets plus the market value of equity less the book value of equity all divided by the book value of assets. Percentage change in Tobin's $Q$ is computed as the difference in the natural logs of the post-crisis and pre-crisis values of Tobin's $Q$. Cumulative stock returns are obtained from Datastream and are not available for 60 firms. Management ownership refers to all stakes held by a firm's officers and directors and their families. This data is obtained from Lins (2000) for the fiscal year closest to December 1995. Management control rights and cash flow ownership rights of a firm include direct ownership as well as the effect of those stakes obtained indirectly via management ownership and control of blockholders in the firm (i.e. pyramid ownership). 'Cash flow rights leverage' is computed as management control rights divided by the cash flow rights associated with those control rights. This measure will be greater than unity where indirect management ownership occurs. Firm size and the debt to total asset ratio is measured from the pre-crisis period. Firm size refers to the total assets of a firm and is reported in millions of U.S. dollars. The "Rule of Law" variable is obtained from La Porta, Lopez-de-Silanes, Shleifer, and Vishny (1998). This measure ranges from 0 to 10 with lower scores corresponding to less tradition for law and order.

Panel A: Sample selection procedure

\begin{tabular}{|c|c|c|c|c|c|c|c|c|c|}
\hline & Hong Kong & Indonesia & Korea & Malaysia & Philippines & Singapore & Taiwan & Thailand & All \\
\hline $\begin{array}{l}\text { Number of non-financial firms on } \\
\text { Worldscope July } 1997 \text { disk }\end{array}$ & 246 & 94 & 188 & 284 & 57 & 160 & 180 & 187 & 1396 \\
\hline $\begin{array}{l}\text { Subtract: } \\
\text { Firms with insufficient data to } \\
\text { compute management control } \\
\text { and cash flow rights ownership }\end{array}$ & 56 & 53 & 32 & 101 & 30 & 56 & 73 & 56 & 457 \\
\hline Remaining firms & 190 & 41 & 156 & 183 & 27 & 104 & 107 & 131 & 939 \\
\hline $\begin{array}{l}\text { Subtract: } \\
\text { Firms with SEDOL changes or } \\
\text { insufficient data to compute } \\
\text { Tobin's Q for pre- and post- } \\
\text { crisis periods }\end{array}$ & 7 & 4 & 8 & 17 & 5 & 11 & 2 & 12 & 86 \\
\hline Final Sample & 163 & 37 & 148 & 166 & 22 & 93 & 105 & 119 & 853 \\
\hline
\end{tabular}


Panel B: Summary Statistics for Final Sample

\begin{tabular}{|l|c|c|c|c|c|c|c|}
\hline & $\mathrm{N}$ & Mean & Median & Min & $1^{\text {st }}$ & $\begin{array}{c}99^{\text {th }} \\
\text { percentile }\end{array}$ & \multicolumn{1}{|c|}{ Max } \\
percentile
\end{tabular}




\section{Table 2}

Summary Statistics by Country

Mean values of summary statistics by country are listed along with median values in parentheses. Tobin's $Q$ is computed as the book value of assets plus the market value of equity less the book value of equity all divided by the book value of assets. Percentage change in Tobin's $Q$ is computed as the difference in the natural logs of the post-crisis and pre-crisis values of Tobin's $Q$. Cumulative stock returns are reported in local currency and are obtained from Datastream. These are not available for 60 firms. Management group control rights and cash flow ownership rights of a firm include direct ownership as well as the effect of those stakes obtained indirectly via management ownership and control of blockholders in the firm (i.e. pyramid ownership). 'Cash flow rights leverage' is computed as management control rights divided by the cash flow rights associated with those control rights. This measure will be greater than unity where indirect management ownership occurs. The "Rule of Law" variable is obtained from La Porta, et al (1998). This measure ranges from 0 to 10 with lower scores corresponding to less tradition for law and order. Ownership variables, total assets, and the debt to total asset ratio are measured from the pre-crisis period.

\begin{tabular}{|c|c|c|c|c|c|c|c|c|}
\hline & Hong Kong & Indonesia & Korea & Malaysia & Philippines & Singapore & Taiwan & Thailand \\
\hline $\begin{array}{l}\text { Percentage change in } Q \text { pre-crisis } \\
\text { to post-crisis }\end{array}$ & $\begin{array}{l}-0.195 \\
(-0.193)\end{array}$ & $\begin{array}{c}-0.152 \\
(-0.087)\end{array}$ & $\begin{array}{c}-0.070 \\
(-0.039)\end{array}$ & $\begin{array}{c}-0.681 \\
(-0.683)\end{array}$ & $\begin{array}{c}-0.329 \\
(-0.348)\end{array}$ & $\begin{array}{c}-0.312 \\
(-0.289)\end{array}$ & $\begin{array}{c}0.031 \\
(-0.021)\end{array}$ & $\begin{array}{l}-0.118 \\
(-0.076)\end{array}$ \\
\hline $\begin{array}{l}\text { Cumulative firm stock returns pre- } \\
\text { crisis to post-crisis }\end{array}$ & $\begin{array}{c}-0.534 \\
(-0.598)\end{array}$ & $\begin{array}{c}-0.258 \\
(-0.515)\end{array}$ & $\begin{array}{c}-0.692 \\
(-0.746)\end{array}$ & $\begin{array}{c}-0.676 \\
(-0.775)\end{array}$ & $\begin{array}{c}-0.379 \\
(-0.429)\end{array}$ & $\begin{array}{c}-0.518 \\
(-0.574)\end{array}$ & $\begin{array}{c}-0.017 \\
(-0.160)\end{array}$ & $\begin{array}{c}-0.257 \\
(-0.424)\end{array}$ \\
\hline $\begin{array}{l}\text { Management group control rights } \\
\text { ownership percentage }\end{array}$ & $\begin{array}{c}0.40 \\
(0.45)\end{array}$ & $\begin{array}{c}0.31 \\
(0.25)\end{array}$ & $\begin{array}{c}0.16 \\
(0.16)\end{array}$ & $\begin{array}{c}0.27 \\
(0.26)\end{array}$ & $\begin{array}{c}0.41 \\
(0.51)\end{array}$ & $\begin{array}{c}0.31 \\
(0.29)\end{array}$ & $\begin{array}{c}0.18 \\
(0.14)\end{array}$ & $\begin{array}{c}0.19 \\
(0.18)\end{array}$ \\
\hline $\begin{array}{l}\text { Management group cash flow } \\
\text { rights leverage }\end{array}$ & $\begin{array}{c}1.45 \\
(1)\end{array}$ & $\begin{array}{l}1.26 \\
(1)\end{array}$ & $\begin{array}{c}2.39 \\
(1)\end{array}$ & $\begin{array}{c}2.46 \\
(1)\end{array}$ & $\begin{array}{c}3.12 \\
(1.11)\end{array}$ & $\begin{array}{c}3.24 \\
(1)\end{array}$ & $\begin{array}{c}2.30 \\
(1)\end{array}$ & $\begin{array}{l}1.55 \\
(1)\end{array}$ \\
\hline Total assets (USD millions) & $\begin{array}{c}947 \\
(205)\end{array}$ & $\begin{array}{c}446 \\
(110)\end{array}$ & $\begin{array}{l}2423 \\
(936)\end{array}$ & $\begin{array}{c}571 \\
(171)\end{array}$ & $\begin{array}{c}389 \\
(158)\end{array}$ & $\begin{array}{c}545 \\
(190)\end{array}$ & $\begin{array}{c}432 \\
(240)\end{array}$ & $\begin{array}{c}413 \\
(128)\end{array}$ \\
\hline Debt to total assets ratio & $\begin{array}{c}0.25 \\
(0.24)\end{array}$ & $\begin{array}{c}0.27 \\
(0.23)\end{array}$ & $\begin{array}{c}0.46 \\
(0.48)\end{array}$ & $\begin{array}{c}0.22 \\
(0.21)\end{array}$ & $\begin{array}{c}0.16 \\
(0.15)\end{array}$ & $\begin{array}{c}0.21 \\
(0.19)\end{array}$ & $\begin{array}{c}0.25 \\
(0.24)\end{array}$ & $\begin{array}{c}0.40 \\
(0.41)\end{array}$ \\
\hline Country 'Rule of Law' score & 8.22 & 3.98 & 5.35 & 6.78 & 2.73 & 8.57 & 8.52 & 6.25 \\
\hline
\end{tabular}




\section{Table 3}

Summary Statistics by Ownership Category

Firms are separated based on cash flow rights leverage which is a measure of whether or not the management and family group employs indirect ownership to obtain some of its control rights. 'Cash flow rights leverage' is computed as management control rights divided by the cash flow rights associated with those control rights. The cash flow rights leverage dummy is set equal to one if cash flow rights leverage is greater than one, and zero if cash flow rights leverage equals one. All other variables are described previously in Tables 1 and 2. Cumulative stock returns are not available for 60 firms. The p-value of the t-test and medians tests of equality is reported in parentheses. Panel A reports broad summary statistics for the full sample. Panel B reports change in valuation statistics for subsamples based on whether or not the firm has above-median (computed within each country) management group control rights ownership. Panel C reports change in valuation statistics for subsamples based on whether or not the control rights held by the management group exceed those of any other blockholder type.

Panel A: Full sample

\begin{tabular}{|c|c|c|c|c|c|c|}
\hline & \multicolumn{2}{|c|}{$\begin{array}{c}\text { Cash flow rights leverage } \\
\text { dummy }=1 \\
(\mathrm{~N}=233)\end{array}$} & \multicolumn{2}{|c|}{$\begin{array}{c}\text { Cash flow rights leverage } \\
\text { dummy }=0 \\
(\mathrm{~N}=620)\end{array}$} & \multicolumn{2}{|c|}{ Difference (p-value) } \\
\hline & Mean & Median & Mean & Median & Mean & Median \\
\hline $\begin{array}{l}\text { Percentage change in } Q \text { pre-crisis } \\
\text { to post-crisis }\end{array}$ & -0.337 & -0.279 & -0.209 & -0.141 & $\begin{array}{l}-0.128 \\
(0.00)\end{array}$ & $\begin{array}{c}-0.138 \\
(0.00)\end{array}$ \\
\hline $\begin{array}{l}\text { Cumulative stock returns pre-crisis } \\
\text { to post-crisis }\end{array}$ & -0.534 & -0.609 & -0.448 & -0.573 & $\begin{array}{r}-0.086 \\
(0.01)\end{array}$ & $\begin{array}{l}-0.036 \\
(0.20)\end{array}$ \\
\hline $\begin{array}{l}\text { Management group control rights } \\
\text { ownership percentage }\end{array}$ & 0.43 & 0.43 & 0.20 & 0.14 & $\begin{array}{c}0.23 \\
(0.00)\end{array}$ & $\begin{array}{c}0.29 \\
(0.00)\end{array}$ \\
\hline $\begin{array}{l}\text { Management group cash flow } \\
\text { rights leverage }\end{array}$ & 5.25 & 3.81 & 1 & 1 & $\begin{array}{l}4.25 \\
(0.00)\end{array}$ & $\begin{array}{c}2.81 \\
(0.00)\end{array}$ \\
\hline Total assets (USD millions) & 885 & 226 & 922 & 222 & $\begin{array}{c}-37 \\
(0.83)\end{array}$ & $\begin{array}{c}4 \\
(0.57)\end{array}$ \\
\hline Debt to total assets ratio & 0.27 & 0.26 & 0.30 & 0.30 & $\begin{array}{l}-0.03 \\
(0.01)\end{array}$ & $\begin{array}{l}-0.04 \\
(0.01)\end{array}$ \\
\hline
\end{tabular}


Panel B: Subsamples based on above- and below-median management group control rights

\begin{tabular}{|c|c|c|c|c|c|c|c|c|}
\hline & \multicolumn{3}{|c|}{$\mathrm{CF}$ rights leverage dummy $=1$} & \multicolumn{3}{|c|}{$\mathrm{CF}$ rights leverage dummy $=0$} & \multicolumn{2}{|c|}{ Difference (p-value) } \\
\hline & $\mathrm{N}$ & Mean & Median & $\mathrm{N}$ & Mean & Median & Mean & Median \\
\hline Above-median management group control rights & & & & & & & & \\
\hline $\begin{array}{l}\text { Percentage change in } Q \text { pre-crisis to } \\
\text { post-crisis }\end{array}$ & 177 & -0.348 & -0.311 & 229 & -0.174 & -0.128 & $\begin{array}{l}-0.174 \\
(0.00)\end{array}$ & $\begin{array}{l}-0.183 \\
(0.00)\end{array}$ \\
\hline $\begin{array}{l}\text { Cumulative stock returns pre-crisis to } \\
\text { post-crisis }\end{array}$ & 168 & -0.567 & -0.626 & 211 & -0.432 & -0.612 & $\begin{array}{l}-0.135 \\
(0.01)\end{array}$ & $\begin{array}{l}-0.015 \\
(0.40)\end{array}$ \\
\hline Below-median management group control rights & & & & & & & & \\
\hline $\begin{array}{l}\text { Percentage change in } Q \text { pre-crisis to } \\
\text { post-crisis }\end{array}$ & 56 & -0.304 & -0.192 & 391 & -0.229 & -0.152 & $\begin{array}{l}-0.075 \\
(0.24)\end{array}$ & $\begin{array}{l}-0.040 \\
(0.22)\end{array}$ \\
\hline $\begin{array}{l}\text { Cumulative stock returns pre-crisis to } \\
\text { post-crisis }\end{array}$ & 51 & -0.427 & -0.554 & 363 & -0.457 & -0.554 & $\begin{array}{l}0.030 \\
(0.66)\end{array}$ & $\begin{array}{l}0.000 \\
(0.59)\end{array}$ \\
\hline
\end{tabular}

Panel C: Subsamples based on whether or not the management group is the largest control rights blockholder

\begin{tabular}{|c|c|c|c|c|c|c|c|c|}
\hline & \multicolumn{3}{|c|}{$\mathrm{CF}$ rights leverage dummy $=1$} & \multicolumn{3}{|c|}{$\mathrm{CF}$ rights leverage dummy $=0$} & \multicolumn{2}{|c|}{ Difference (p-value) } \\
\hline & $\mathrm{N}$ & Mean & Median & $\mathrm{N}$ & Mean & Median & Mean & Median \\
\hline Management group is the largest blockholder & & & & & & & & \\
\hline $\begin{array}{l}\text { Percentage change in } Q \text { pre-crisis to } \\
\text { post-crisis }\end{array}$ & 223 & -0.340 & -0.298 & 352 & -0.159 & -0.116 & $\begin{array}{l}-0.181 \\
(0.00)\end{array}$ & $\begin{array}{r}-0.182 \\
(0.00)\end{array}$ \\
\hline $\begin{array}{l}\text { Cumulative stock returns pre-crisis to } \\
\text { post-crisis }\end{array}$ & 209 & -0.539 & -0.623 & 323 & -0.445 & -0.586 & $\begin{array}{l}-0.094 \\
(0.02)\end{array}$ & $\begin{array}{l}-0.037 \\
(0.36)\end{array}$ \\
\hline Management group is not the largest blockholder & & & & & & & & \\
\hline $\begin{array}{l}\text { Percentage change in } Q \text { pre-crisis to } \\
\text { post-crisis }\end{array}$ & 10 & -0.275 & -0.208 & 268 & -0.273 & -0.184 & $\begin{array}{l}-0.002 \\
(0.99)\end{array}$ & $\begin{array}{l}-0.024 \\
(0.63)\end{array}$ \\
\hline $\begin{array}{l}\text { Cumulative stock returns pre-crisis to } \\
\text { post-crisis }\end{array}$ & 10 & -0.433 & -0.459 & 251 & -0.452 & -0.554 & $\begin{array}{l}0.019 \\
(0.83)\end{array}$ & $\begin{array}{l}0.095 \\
(0.34)\end{array}$ \\
\hline
\end{tabular}


Table 4

The Effect of Ownership Structure on Percentage Change in Tobin's $Q$ During the Crisis

The dependent variable for all regressions is the percentage change in Tobin's $Q$ during the crisis period. Tobin's $Q$ is computed as the book value of assets plus the market value of equity less the book value of equity all divided by the book value of assets. The percentage change in Tobin's $Q$ is computed as the difference in the natural logs of the post-crisis and pre-crisis values of Tobin's $Q$ and has been truncated at the first and ninety-ninth percentiles to alleviate problems with outliers. Model (1) is estimated using the full sample. Models (2) and (3) are estimated for subsamples based on whether a firm has above or below-median management/family group ownership within its country. Models (4) and (5) are estimated for subsamples based on whether or not the management/family group is the largest blockholder of a firm. Regressions are estimated with two-digit primary SIC code fixed effects and country random effects (coefficients not reported). The cash flow rights leverage dummy is set equal to one if cash flow rights leverage is greater than one, and zero if cash flow rights leverage equals one. Cash flow rights leverage is computed as management control rights divided by the cash flow rights associated with those control rights. This measure will be greater than unity where indirect management ownership occurs. The "Rule of Law" variable is obtained from La Porta, Lopez-de-Silanes, Shleifer, and Vishny (1998). This measure ranges from 0 to 10 with lower scores corresponding to less tradition for law and order. Ownership variables, total assets, and the debt to total asset ratio are measured from the pre-crisis period and are described further in Tables 1 and 2. P-values are in parentheses below each coefficient.

\begin{tabular}{|c|c|c|c|c|c|}
\hline Independent variables & $\begin{array}{l}\text { Full } \\
\text { sample }\end{array}$ & $\begin{array}{l}\text { High } \\
\text { mgmt } \\
\text { control } \\
\text { rights }\end{array}$ & $\begin{array}{l}\text { Low } \\
\text { mgmt } \\
\text { control } \\
\text { rights }\end{array}$ & $\begin{array}{l}\text { Mgmt is the } \\
\text { largest } \\
\text { blockholder }\end{array}$ & $\begin{array}{l}\text { Mgmt is not } \\
\text { the largest } \\
\text { blockholder }\end{array}$ \\
\hline & (1) & $(2)$ & (3) & (4) & (5) \\
\hline $\begin{array}{l}\text { Cash flow rights leverage } \\
\text { dummy }\end{array}$ & $\begin{array}{l}-0.123 \\
(0.00)\end{array}$ & $\begin{array}{l}-0.139 \\
(0.00)\end{array}$ & $\begin{array}{l}-0.134 \\
(0.01)\end{array}$ & $\begin{array}{l}-0.153 \\
(0.00)\end{array}$ & $\begin{array}{l}-0.005 \\
(0.96)\end{array}$ \\
\hline Rule of Law measure & $\begin{array}{l}0.021 \\
(0.02)\end{array}$ & $\begin{array}{c}0.018 \\
(0.15)\end{array}$ & $\begin{array}{l}0.027 \\
(0.03)\end{array}$ & $\begin{array}{l}0.022 \\
(0.03)\end{array}$ & $\begin{array}{l}0.017 \\
(0.30)\end{array}$ \\
\hline Log of total assets & $\begin{array}{l}0.044 \\
(0.00)\end{array}$ & $\begin{array}{l}0.064 \\
(0.00)\end{array}$ & $\begin{array}{l}0.028 \\
(0.03)\end{array}$ & $\begin{array}{l}0.060 \\
(0.00)\end{array}$ & $\begin{array}{l}0.020 \\
(0.17)\end{array}$ \\
\hline Debt to total assets ratio & $\begin{array}{c}0.513 \\
(0.00)\end{array}$ & $\begin{array}{l}0.362 \\
(0.01)\end{array}$ & $\begin{array}{c}0.689 \\
(0.00)\end{array}$ & $\begin{array}{l}0.367 \\
(0.00)\end{array}$ & $\begin{array}{c}0.784 \\
(0.00)\end{array}$ \\
\hline Industry Dummies & Yes & Yes & Yes & Yes & Yes \\
\hline Overall R-squared & 0.24 & 0.26 & 0.30 & 0.25 & 0.38 \\
\hline Number of observations & 837 & 400 & 437 & 567 & 270 \\
\hline
\end{tabular}


Table 5

The Effect of Ownership Structure on Cumulative Stock Returns During the Crisis

The dependent variable for all regressions is the cumulative stock return during the crisis period. The sample is the same as that used in Table 4 except that cumulative stock returns (obtained from Datastream) are not available for 60 firms. Model (1) is estimated using the full sample. Models (2) and (3) are estimated for subsamples based on whether a firm has above or below-median management/family group ownership within its country. Models (4) and (5) are estimated for subsamples based on whether or not the management/family group is the largest blockholder of a firm. Regressions are estimated with two-digit primary SIC code fixed effects and country random effects (coefficients not reported). The cash flow rights leverage dummy is set equal to one if cash flow rights leverage is greater than one, and zero if cash flow rights leverage equals one. Cash flow rights leverage is computed as management control rights divided by the cash flow rights associated with those control rights. This measure will be greater than unity where indirect management ownership occurs. The "Rule of Law" variable is obtained from La Porta, Lopez-de-Silanes, Shleifer, and Vishny (1998). This measure ranges from 0 to 10 with lower scores corresponding to less tradition for law and order. Ownership variables, total assets, and the debt to total asset ratio are measured from the pre-crisis period and are described further in Tables 1 and 2. Pvalues are in parentheses below each coefficient.

\begin{tabular}{|c|c|c|c|c|c|}
\hline Independent variables & $\begin{array}{l}\text { Full } \\
\text { sample }\end{array}$ & $\begin{array}{l}\text { High } \\
\text { mgmt } \\
\text { control } \\
\text { rights }\end{array}$ & $\begin{array}{c}\text { Low } \\
\text { mgmt } \\
\text { control } \\
\text { rights }\end{array}$ & $\begin{array}{l}\text { Mgmt is the } \\
\text { largest } \\
\text { blockholder }\end{array}$ & $\begin{array}{l}\text { Mgmt is not } \\
\text { the largest } \\
\text { blockholder }\end{array}$ \\
\hline & $(1)$ & $(2)$ & $(3)$ & (4) & (5) \\
\hline $\begin{array}{l}\text { Cash flow rights leverage } \\
\text { dummy }\end{array}$ & $\begin{array}{l}-0.092 \\
(0.01)\end{array}$ & $\begin{array}{l}-0.122 \\
(0.03)\end{array}$ & $\begin{array}{l}0.048 \\
(0.46)\end{array}$ & $\begin{array}{l}-0.090 \\
(0.04)\end{array}$ & $\begin{array}{l}-0.034 \\
(0.81)\end{array}$ \\
\hline Rule of Law measure & $\begin{array}{l}0.046 \\
(0.00)\end{array}$ & $\begin{array}{l}0.030 \\
(0.12)\end{array}$ & $\begin{array}{l}0.054 \\
(0.00)\end{array}$ & $\begin{array}{l}0.050 \\
(0.00)\end{array}$ & $\begin{array}{l}0.009 \\
(0.68)\end{array}$ \\
\hline Log of total assets & $\begin{array}{l}-0.022 \\
(0.10)\end{array}$ & $\begin{array}{r}-0.048 \\
(0.04)\end{array}$ & $\begin{array}{l}-0.001 \\
(0.99)\end{array}$ & $\begin{array}{l}-0.033 \\
(0.06)\end{array}$ & $\begin{array}{l}0.004 \\
(0.81)\end{array}$ \\
\hline Debt to total assets ratio & $\begin{array}{l}-0.145 \\
(0.16)\end{array}$ & $\begin{array}{l}-0.094 \\
(0.56)\end{array}$ & $\begin{array}{l}-0.285 \\
(0.03)\end{array}$ & $\begin{array}{l}-0.088 \\
(0.49)\end{array}$ & $\begin{array}{l}-0.581 \\
(0.00)\end{array}$ \\
\hline Industry Dummies & Yes & Yes & Yes & Yes & Yes \\
\hline Overall R-squared & 0.19 & 0.16 & 0.43 & 0.17 & 0.56 \\
\hline Number of observations & 777 & 373 & 404 & 524 & 253 \\
\hline
\end{tabular}


Table 6

The Effect of Ownership Structure on Percentage Change in Tobin's $Q$ Before the Crisis

The dependent variable for all regressions is the Percentage change in Tobin's $Q$ for the year prior to the crisis period. Tobin's $Q$ is computed as the book value of assets plus the market value of equity less the book value of equity all divided by the book value of assets. The percentage change in Tobin's $Q$ is computed as the difference in the natural logs of the post-crisis and pre-crisis values of Tobin's $Q$ and has been truncated at the first and ninety-ninth percentiles to alleviate problems with outliers. Model (1) is estimated using the full sample. Models (2) and (3) are estimated for subsamples based on whether a firm has above or below-median management/family group ownership within its country. Models (4) and (5) are estimated for subsamples based on whether or not the management/family group is the largest blockholder of a firm. Regressions are estimated with two-digit primary SIC code fixed effects and country random effects (coefficients not reported). The cash flow rights leverage dummy is set equal to one if cash flow rights leverage is greater than one, and zero if cash flow rights leverage equals one. Cash flow rights leverage is computed as management control rights divided by the cash flow rights associated with those control rights. This measure will be greater than unity where indirect management ownership occurs. The "Rule of Law" variable is obtained from La Porta, Lopez-de-Silanes, Shleifer, and Vishny (1998). This measure ranges from 0 to 10 with lower scores corresponding to less tradition for law and order. Ownership variables, total assets, and the debt to total asset ratio are measured from the pre-crisis period and are described further in Tables 1 and 2. P-values are in parentheses below each coefficient.

\begin{tabular}{|c|c|c|c|c|c|}
\hline Independent variables & $\begin{array}{c}\text { Full } \\
\text { sample }\end{array}$ & $\begin{array}{l}\text { High } \\
\text { mgmt } \\
\text { control } \\
\text { rights }\end{array}$ & $\begin{array}{c}\text { Low } \\
\text { mgmt } \\
\text { control } \\
\text { rights }\end{array}$ & $\begin{array}{l}\text { Mgmt is the } \\
\text { largest } \\
\text { blockholder }\end{array}$ & $\begin{array}{l}\text { Mgmt is not } \\
\text { the largest } \\
\text { blockholder }\end{array}$ \\
\hline & $(1)$ & $(2)$ & (3) & (4) & $(5)$ \\
\hline $\begin{array}{l}\text { Cash flow rights leverage } \\
\text { dummy }\end{array}$ & $\begin{array}{l}0.004 \\
(0.91)\end{array}$ & $\begin{array}{l}-0.012 \\
(0.64)\end{array}$ & $\begin{array}{l}0.008 \\
(0.81)\end{array}$ & $\begin{array}{l}-0.012 \\
(0.55)\end{array}$ & $\begin{array}{l}0.084 \\
(0.34)\end{array}$ \\
\hline Rule of Law measure & $\begin{array}{l}0.027 \\
(0.00)\end{array}$ & $\begin{array}{c}0.030 \\
(0.00)\end{array}$ & $\begin{array}{l}0.028 \\
(0.00)\end{array}$ & $\begin{array}{l}0.029 \\
(0.00)\end{array}$ & $\begin{array}{l}0.017 \\
(0.19)\end{array}$ \\
\hline Log of total assets & $\begin{array}{r}-0.002 \\
(0.73)\end{array}$ & $\begin{array}{c}0.008 \\
(0.41)\end{array}$ & $\begin{array}{c}-0.008 \\
(0.39)\end{array}$ & $\begin{array}{c}0.002 \\
(0.78)\end{array}$ & $\begin{array}{c}-0.004 \\
(0.74)\end{array}$ \\
\hline Debt to total assets ratio & $\begin{array}{c}-0.006 \\
(0.91)\end{array}$ & $\begin{array}{c}-0.001 \\
(0.99)\end{array}$ & $\begin{array}{c}-0.008 \\
(0.91)\end{array}$ & $\begin{array}{c}0.044 \\
(0.46)\end{array}$ & $\begin{array}{c}-0.146 \\
(0.13)\end{array}$ \\
\hline Industry Dummies & Yes & Yes & Yes & Yes & Yes \\
\hline Overall R-squared & 0.12 & 0.17 & 0.17 & 0.14 & 0.21 \\
\hline Number of observations & 840 & 400 & 440 & 570 & 270 \\
\hline
\end{tabular}




\section{DAVIDSON INSTITUTE WORKING PAPER SERIES - Most Recent Papers}

The entire Working Paper Series is available at: www.wdi.bus.umich.edu

CURRENT AS OF 10/30/01

\begin{tabular}{|c|c|c|}
\hline Publication & Authors & Date \\
\hline $\begin{array}{l}\text { No. 400: Do External Auditors Perform a Corporate Governance Role in } \\
\text { Emerging Markets? Evidence from East Asia }\end{array}$ & Joseph P. H. Fan and T.J. Wong & Oct. 2001 \\
\hline $\begin{array}{l}\text { No. 399: Financial Conditions and Investment during the Transition: } \\
\text { Evidence from Czech Firms }\end{array}$ & Lubomír Lízal and Jan Svejnar & Oct. 2001 \\
\hline $\begin{array}{l}\text { No. 398: Accessible Pareto-Improvements: Using Market Information to } \\
\text { Reform Inefficiencies }\end{array}$ & Michael Mandler & May 2001 \\
\hline No. 397: The Making of an Integrated National Grain Market in China & Wubiao Zhou & Oct. 2001 \\
\hline No. 396: Corruption and Resource Allocation: Evidence from China & Wei Li & June 2001 \\
\hline $\begin{array}{l}\text { No. 395: Government Shareholding and the Value of China's Modern } \\
\text { Firms }\end{array}$ & Lihui Tian & Apr. 2001 \\
\hline No. 394: Labor Hoarding in Russia: Where Does it Come from? & $\begin{array}{l}\text { Rouslan Koumakhov and Boris } \\
\text { Najman }\end{array}$ & June 2000 \\
\hline $\begin{array}{l}\text { No. 393: Ownership Structure, Corporate Governance, And Firm Value: } \\
\text { Evidence from the East Asian Financial Crisis }\end{array}$ & Michael Lemmon and Karl Lins & Apr. 2001 \\
\hline No. 392: Marshall and Labour Demand in Russia: Going Back to Basics & $\begin{array}{l}\text { Jozef Konings and Hartmut } \\
\text { Lehmann }\end{array}$ & Aug. 2001 \\
\hline No. 391: Economic Transition and Elections in Poland & $\begin{array}{l}\text { John E. Jackson, Jacek Klich, and } \\
\text { Krystyna Poznańska }\end{array}$ & June 2001 \\
\hline $\begin{array}{l}\text { No. 390: Effects of Bank Insolvency and Strategic Uncertainty on } \\
\text { Corporate Restructuring in Transition Economies }\end{array}$ & Christa Hainz & Aug. 2001 \\
\hline No. 389: Mark-Up Pricing In Bulgarian Manufacturing & $\begin{array}{l}\text { Rumen Dobrinsky, Boyko } \\
\text { Nikolov, and Nikolay Markov }\end{array}$ & June 2001 \\
\hline $\begin{array}{l}\text { No. } 388 \text { Globalization and Fir } \\
\text { Evidence from Emerging Eco }\end{array}$ & $\begin{array}{l}\text { Sergio Schmukler and Esteban } \\
\text { Vesperoni }\end{array}$ & May 2001 \\
\hline $\begin{array}{l}\text { No. } 387 \text { The Distributional Impacts of Indonesia's Financial Crisis on } \\
\text { Household Welfare: A "Rapid Response" Methodology }\end{array}$ & $\begin{array}{l}\text { Jed Friedman and James } \\
\text { Levinsohn }\end{array}$ & Sept. 2001 \\
\hline $\begin{array}{l}\text { No. } 386 \text { Corporate Financial Policies and Performance Prior to Currency } \\
\text { Crises }\end{array}$ & $\begin{array}{l}\text { Arturo Bris, Yrjö Koskinen, and } \\
\text { Vicente Pons }\end{array}$ & June 2001 \\
\hline No. 385 Ownership and Productive Efficiency: Evidence from Estonia & Derek C. Jones and Niels Mygind & Aug. 2001 \\
\hline $\begin{array}{l}\text { No. } 384 \text { Forthcoming in: Journal of Economic Perspectives, } \\
\text { "Institutional Determinants of Labor Reallocation in Transition" Vol. } \\
\text { 16, No. 2, Feb. } 2002 \text {. }\end{array}$ & Tito Boeri and Katherine Terrell & June 2001 \\
\hline $\begin{array}{l}\text { No. } 383 \text { Deindustrialisation and Structural Change During the Post- } \\
\text { Communist Transition }\end{array}$ & $\begin{array}{l}\text { Tomasz Mickiewicz and Anna } \\
\text { Zalewska }\end{array}$ & June 2001 \\
\hline No. 382 Markets and Growth & Štěpán Jurajda and Janet Mitchell & July 2001 \\
\hline $\begin{array}{l}\text { No. } 381 \text { Labor Market Discrimination During Post-Communist } \\
\text { Transition: A Monopsony Approach to the Status of Latvia's Russian } \\
\text { Minority }\end{array}$ & Robert S. Chase & Sept. 2000 \\
\hline No. 380 Dollarization of Liabilities in Non-tradable Goods Sector & Frédéric Chabellard & June 2001 \\
\hline $\begin{array}{l}\text { No. } 379 \text { Lessons from the Russian Meltdown: The Economics of Soft } \\
\text { Legal Constraints }\end{array}$ & Enrico Perotti & Mar. 2001 \\
\hline No. 378 Effective Tax Rates in Transition & Vlad Ivanenko & May 2001 \\
\hline $\begin{array}{l}\text { No. } 377 \text { Some Explanations for Changes in the Distribution of } \\
\text { Household Income in Slovakia: } 1988 \text { and } 1996\end{array}$ & $\begin{array}{l}\text { Thesia Garner and Katherine } \\
\text { Terrell }\end{array}$ & May 2001 \\
\hline $\begin{array}{l}\text { No. } 376 \text { Competition and Enterprise Performance in Transition } \\
\text { Economies: Evidence from a Cross-country Survey }\end{array}$ & $\begin{array}{l}\text { Wendy Carlin, Steven Fries, } \\
\text { Mark Schaffer and Paul Seabright }\end{array}$ & May 2001 \\
\hline $\begin{array}{l}\text { No. } 375 \text { Why More is Actually Less: New Interpretations of China's } \\
\text { Labor-Intensive FDI }\end{array}$ & Yasheng Huang & May 2001 \\
\hline No. 374 Economic Fragmentation and FDI in China & Yasheng Huang & May 2001 \\
\hline
\end{tabular}

